\title{
Investigation of Relationship between High School Students' Career Adaptability, Subjective Well-Being and Perceived Social Support
}

\author{
İrem Şahin ${ }^{1} \&$ Oğuzhan Kırdök ${ }^{1}$ \\ ${ }^{1}$ Faculty of Education, Çukurova University, Adana, Turkey \\ Correspondence: Oğuzhan Kırdök, Faculty of Education, Çukurova University, Sarıçam/Adana, Turkey. Tel: \\ 90-322-338-6733. E-mail: okirdok@cu.edu.tr
}

Received: February 21, 2018

Accepted: April 6, $2018 \quad$ Online Published: July 28, 2018

doi:10.5539/ies.v11n8p127

URL: https://doi.org/10.5539/ies.v11n8p127

\begin{abstract}
The purpose of this study is to examine the relationship between high school students' social support, career adaptability and subjective well-being that are perceived from their family, teachers and friends. The study group consisted of 325 students (193 girls, 132 males) in three secondary schools located in Cukurova and Yüreğir districts of Adana city. The data were collected through Career Adaptability Scale, Life Satisfaction Scale, Positive and Negative Affect Schedule and Perceived Social Support Scale and Personal Information Form developed by the researchers to reach the demographic information of the participants. A path analysis was conducted within the framework of structural equation modeling to investigate the relationship between social support, career adaptability and subjective well-being that the students perceived. Data analysis was done through SPSS and AMOS package programs. Correlation coefficients of arithmetic mean, standard deviation, pearson moment analysis were calculated, and path analysis was performed based on the observed variables. The research findings show that there is a significant relationship between subjective well-being, career adaptability and perceived social support. The perceived social support from family, teachers and friends are variables that predict the career adaptability of high school students. Career adaptability has also been found to be a significant predictor of subjective well-being.
\end{abstract}

Keywords: career adaptability, subjective well-being, perceived social support, high school students

\section{Introduction}

In today's world, individuals are confronted with immediate or long-term changes in almost every aspect of their lives. Adaptability can be defined as adaptation and change to new or changing situations without challenging difficulties (Savickas, 1997). In accordance with the changes in individuals' lives, international paradigms, widespread restructuring and the rapid development and change of the global labour market also render the career of the individuals more important than it was before (Restubog, Bordia, \& Bordia, 2011). Being able to cope with the obstacles that the person experiences in the career process can also be interpreted as adaptability. Career adaptability is defined as the skill to be prepared for foreseeable tasks for participation in the business world, and being prepared to cope with unpredictable situations arising from changes in work and working conditions (Savickas, 1997). It is clear that career adaptability has been a noteworthy concept in recent years. Within the framework of career adaptability; career decision making and relational support (Cheung \& Jin, 2016), academic achievement (Negru-Subtirica \& Pop, 2016), future orientation (Ginevra, Pallini, Vecchio, Nota, \& Soresi, 2016), social comparison (Wong \& Fu, 2015), social support and career satisfaction (Han \& Rojewski, 2015), family support, career decision making and self-efficacy (Guan, Capezio, Restubog, Read, Lajom, \& Li, 2016) are among the concepts that are studied with different groups of samples.

Career processes, including career adaptability, are related to subjective well-being (happiness) in the context of the individual's internal processes (Konstam, Celen-Demirtas, Tomek, \& Sweeney, 2015). Myers and Diener (1995) defined subjective well-being as positive emotions as well as low levels of satisfaction from life as well as low levels of negative emotions. Research has shown that subjective well-being consists of two dimensions (Diener, 2001; Myers, 2000). The cognitive dimension of subjective well-being is described as life satisfaction, and affective dimension refers to positive and negative affect (Doğan, 2013).

The concept of life satisfaction is expressed as a multidimensional evaluation of a person's quality of life (Shin \& Johnson, 1978). Some studies show that life satisfaction is affected by events in life, personal characteristics and 
psychosocial variables (Headey \& Wearing, 1989; Diener, 1996; Lu, 1999; Dost, 2007). Işık (2014) also found that there is a significant relationship between individual's career development characteristics and life satisfaction.

Emotions can be defined as the affective response of individuals to a certain emotional tendency towards other individuals and situations in the face of life events (Oral \& Köse, 2011). There are two types of affect, positive and negative. Positive affect refers to positive views towards life; negative affect denotes negative views towards life (Grandey, Tam, \& Brauburger, 2002). Once individuals are born, they need support from external environment that may provide happiness when they try to manage adaptation and adaptability processes. This support is primarily family and, in time, the social circle that the individual creates. In this context, it can be said that social support, which is related to career adaptability and subjective well-being, means getting all kinds of support and assistance from the sources that affect them such as family, friends or an important person (Cohen \& Hoberman, 1983). Factors such as the core family of individuals, the extended family environment, friends, partners, teachers/trainers, co-workers, intellectuals, religious or ethnic groups and societies in which individuals live constitute social support resources of individuals (Yıldırım, 1997). Individuals have a social interaction with each of these resources and receive social support from each of these resources. The studies show that there is a relationship between subjective well-being and career adaptability (Celen-Demirtas, Konstam, \& Tomek, 2015, Konstam et al., 2015), career adaptability and social support (Guan et al., 2016, Han \& Rojewski, 2015) and subjective well-being and social support (Saygın \& Arslan, 2009; Şahin, 2011).Considering the human development, adolescence is one of the periods of many changes and developments that take place including career adaptability (Ginevra, Magnano, Lodi, Annovazzi, Camussi, Patrizi, \& Nota, 2018; Hirschi, 2009), subjective well-being (Canbay, 2010; Eryılmaz \& Hasan, 2011; Eryılmaz, 2010) and social support (Yıldırım, 1998; Y1ldırım \& Ergene, 2003) which are important in an individual's life.

In line with this view, differ from other research conducted in the field this research aims to reveal the relationship between career adaptability and subjective well-being of perceived social support from the family, teachers and friends from high school.

\section{Methodology}

This research is a descriptive study aiming to examine the relationship between high school students' perceived social support from family, teachers and friends, career adaptability and subjective well-being. In parallel with the purpose of the study, path analysis was preferred in the study because it reveals the causal relationship between multiple variables at the same time. Path analysis is a method that reveals direct and indirect causality between dependent and independent variables through structural equations (Özdamar, 2016, p.217). A path analysis was conducted within the framework of structural equation modelling to investigate the relationship between students' perceived social support, career adaptability and subjective well-being. In line with this goal, the theoretical model in Figure 1 was created based on the previous studies in the related literature.

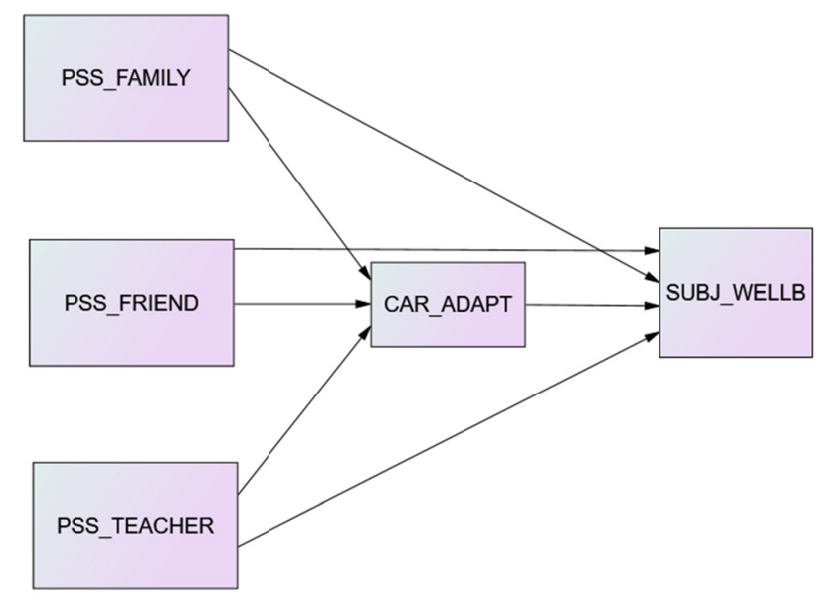

Figure 1. Theoretical model to investigate relationships between perceived social support from family, teachers and friends, career adaptability and subjective well-being

PSS_FAMILY= Perceived Social Support from Family, PSS_FRIEND= Perceived Social Support from Friends, PSS_TEACHER $=$ Perceived Social Support from Teachers, CAR_ADAPT $=$ Career adaptability, SUBJ_WELLB= Subjective Well- being 


\subsection{Participants}

The study group was comprised of $9(n=99), 10(n=97), 11(n=83)$ and $12(n=46)$ classes of three secondary education institutions located in the districts of Çukurova and Yüreğir in the city of Adana. (59\%), male (49\%) and the total of 325 students were involved in the study. The ages of the participants ranged from 14 to 19 and the average age was $15.96(\mathrm{sd}=1.15)$.

\subsection{Data Collection Tools}

Career Adaptability Scale, Life Satisfaction Scale, Positive and Negative Affect Schedule, and Perceived Social Support Scale were used to collect data. In addition, the Personal Information Form was used to reach the demographic information of the participants.

Career Adapt-Abilities Scale: This scale consists of 24 items and 4 components (concern, control, curiosity and confidence) in 5-point Likert-type Scale developed by Porfeli and Savickas (2012) and adapted to Turkish by Büyükgöze-Kavas (2014). For each subscale of Büyükgöze-Kavas (2014), Cronbach's Alpha internal consistency coefficients were .77 for concern, .74 for control, .87 for curiosity and .93 for confidence. In this study, the Cronbach Alpha internal consistency coefficient of the career adaptability scale was found to be .75 .

Life Satisfaction Scale: The scale developed by Diener, Emmos, Larsen and Griffin (1985) and adapted to Turkish by Köker (1991) consists of 5 items and one dimension in 7-point Likert-type scale. In the study conducted by Yetim (1993), the Cronbach Alpha internal consistency coefficient of the scale was .86, while the Cronbach Alpha internal consistency coefficient of the scale was .80 in this study.

Positive and Negative Affect Schedule: The scale, developed by Watson, Clark and Tellegen (1988) and adapted to Turkish by Gençöz (2000), consists of 20 items from 10 positives and 10 negative emotional expressions with a Likert type of 5. Gençöz (2000) found that Cronbach's Alpha internal consistency coefficient was .83 for the positive emotional dimension and .86 for the negative emotional dimension. In this study, Cronbach's Alpha internal consistency number was found to be .74 for the positive emotional dimension and .74 for the negative emotional dimension.

Perceived Social Support Scale: The scale developed in Turkish culture by Ylldırım (1997) consists of 50 items and 3 components (family, friend and teacher) in the form of 3-point Likert types. Yildırim (1997) found the Cronbach Alpha internal consistency coefficient of the scale to be .93. In this study, the Cronbach's alpha internal consistency coefficient for each subscale of perceived social support was found to be .76 in the family dimension, .76 in the friend dimension and .75 in the teacher dimension.

Personal Information Form: Participants in the personal information form prepared by the researchers in order to obtain the demographic information of the participants such as gender, age, and class levels.

Procedure: This study was carried out in three different secondary education institutions located in the provinces of Adana province Çukurova and Yüreğir after the necessary permissions were granted from Adana Provincial National Education Directorate in the spring semester of the 2016-2017 academic year. The data were collected by the researchers through the schools, by entering the classrooms, by distributing the scale forms to the students, and by collecting them after the application period of 15-20 minutes.

Data Analysis: The analysis of the data was done through SPSS and AMOS package programs. Correlation coefficients of arithmetic mean, standard deviation, Pearson moment product were calculated and path analysis was performed with the observed variables. A significance level of .05 was considered in the data analysis process.

\section{Results}

The Pearson correlation coefficients showing the relationship between perceived social support, career adaptability, arithmetic average, standard deviation values and variables are given in Table 1. 
Table 1. Descriptive statistics of perceived social support from family, teachers and friends, career adaptability and subjective well-being

$\mathrm{n}=325 * * \mathrm{p}<.001$

\begin{tabular}{lccccc}
\hline Variables & 1 & 2 & 3 & 4 & 5 \\
\hline 1.PSS_FAMILY & 1 & & & & \\
2. PSS_FRIEND. & $.25^{* *}$ & 1 & & & \\
3. PSS_TEACHER. & $.29 * *$ & $.18^{* *}$ & 1 & & \\
4. Career Adaptability & $.31^{* *}$ & $.21^{* *}$ & $.24 * *$ & 1 & \\
5. Subjective Well-being & $.52^{* *}$ & $.23^{* *}$ & $.37 * *$ & $.58^{* *}$ & 1 \\
X & 50.15 & 33.86 & 37.71 & 84.46 & .00 \\
Ss & 8.80 & 5.13 & 10.35 & 15.13 & 2.16 \\
\hline
\end{tabular}

(PSS_FAMILY= Perceived Social Support from Family, PSS_FRIEND= Perceived Social Support from Friends, PSS_TEACHER $=$ Perceived Social Support from Teachers)

As it is seen in Table 1, it can be said that all the variables examined within the scope of the research are meaningful relations between each other. The highest correlation value was found between subjective well-being and career adaptability $(\mathrm{r}=58, \mathrm{p}<.001)$ and perceived social support from family $(\mathrm{r}=52, \mathrm{p}<.001)$. The lowest correlation value between variables was the perceived social support from teacher $(r=18, p<.001)$, career adaptability $(\mathrm{r}=21, \mathrm{p}<.001)$ and subjective well-being $(\mathrm{r}=23, \mathrm{p}<.001)$.

As a result of the correlation analysis, path analysis was conducted within the framework of the structural equation model based on the relations between the variables discussed in the study. In addition, the effects of the variables and the fit index of the theoretical model were examined.

The structural model created to realize the purpose of the study (Figure 1) was tested by path analysis with AMOS. The variables in the model analysis were taken as the observed variables. The maximum likelihood method is used in the analysis of the variables.

As a result of the analysis, it was found that the theoretical model relations formed within the scope of the research, as seen in Figure 2, are significant. The relationship between social support perceived only from a friend and subjective well-being was found not to be significant. The findings show that social support perceived by the family $(\beta=.24, \mathrm{p}<.001)$, teacher $(\beta=.15, \mathrm{p}<.001)$ and friends $(\beta=.12, \mathrm{p}<.001)$ were significant predictors of career adaptability, and three variables account for $14 \%$ of the variance.

While it was found that the perceived social support was significant predictors of subjective well-being $(\beta=.43, \mathrm{p}$ $<.001)$, family $(\beta<.32, \mathrm{p}<.001)$ and teacher $(\beta=.17, \mathrm{p}<.001)$, social support perceived from a friend $(\beta=.04$, $\mathrm{p}>.05$ ) was found not to be a significant predictor of subjective well-being. The subjective well-being of these variables accounts for $.49 \%$ of the variance.

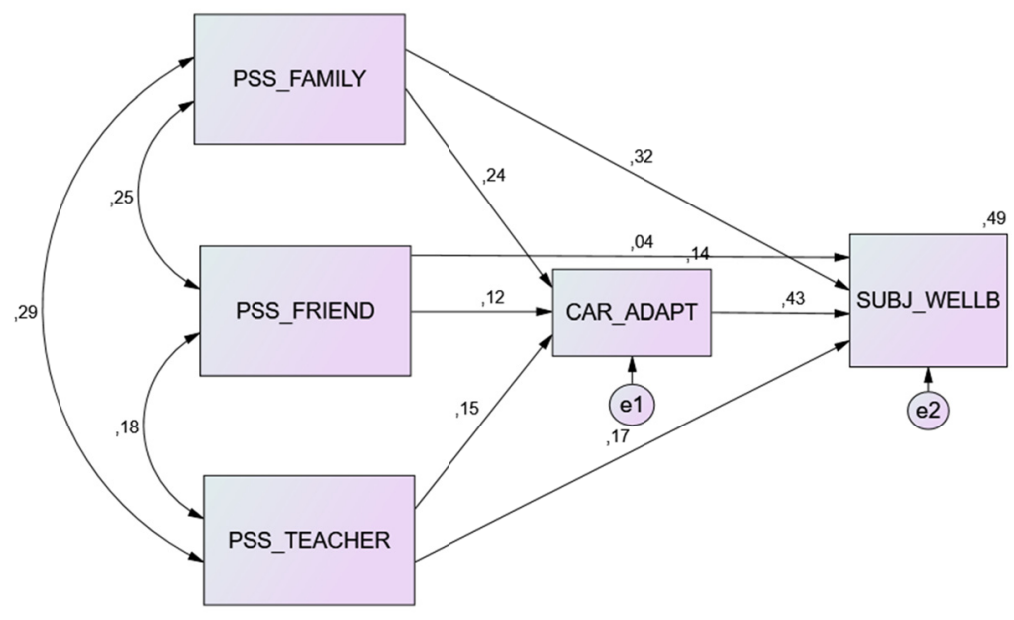

Figure 2. Path analysis results to investigate relationships between perceived social support from family, teachers and friends, career adaptability and subjective well-being 
When the indices of the model are examined, it can be seen that $\mathrm{x} 2=0$ was found. The fact that the value of the chi-square is zero indicates that there is no significant difference between the expected and observed covariance matrices and that it perfectly represents the observed cross-table (Çokluk, Şekercioğlu, \& Büyüköztürk, 2014). The fact that the chi-square is zero indicates that the theoretical model formed is a saturated model by representing all possible ways in the model (Bayram, 2013). Therefore, all the adaptability measures analyzed show excellent adaptability values. $(x 2 / \mathrm{Sd}=0, \mathrm{RMSEA}=0, \mathrm{GFI}=1, \mathrm{CFI}=1, \mathrm{SRMR}=0)$. In this case, it can be said that the model perfectly matches.

\section{Discussion}

In this study, the relationship between social support, career adaptability and subjective well-being of family members, teachers and friends of 325 high school students aged between 14 and 19 was examined. The findings of the study revealed that all the variables (social support, perceived social support from the family, friends and teachers, subjective well-being, and career adaptability) refer to significant relations between each other.

When research findings are examined, the relationship between subjective well-being and career adaptability and perceived social support from family is highest; the relationship between subjective well-being and career adaptability and the perceived support from the teacher was lower. In addition to this, the relationship between perceived social support from friends and career adaptability and subjective well-being is relatively low. Research into social support and career adaptability (Wang \& Fu, 2015; Han \& Rojewksi, 2015), perceived school support and family support (Han \& Rojewski), perceived parental support and career adaptability (Guan et al., 2016) emphasizes the relationship between career adaptability and subjective well-being (Konstam et al., 2015).

Individuals are not independent of the social circle; accordingly, the ability to cope with possible occupational concerns depends on situational variables such as social support (Weisenberg \& Aghakhani, 2007). In a meta-analysis of their work, Viswesvaran, Sanchez and Fisher (1999) concluded that social support has a direct and protective effect on career stress. Social support is an important resource for occupational knowledge and advice as well as for coping with changes (Creed, Fallon \& Hood, 2008). It has been observed that the social support provided to the students in the career field consists of the educational institution, family and friends (Weisenberg \& Aghakhani, 2007). Research has shown that social support perceived by adolescents is important for related processes, including career development and career adaptability (Kracke, 2002; Rogers, Creed, \& Glendon, 2008; Hirschi, 2009). According to the findings, perceived social support from the family by adolescents seems to be the highest predictor of career adaptability. This is because the perceived support from the family always remains primary for individuals, which can be explained by the parental support of adolescents at verbal, emotional and financial levels. Parents are seen as the first role model sources during adolescence (Turner \& Lapan, 2002). This perceived support received from the parent supports the development of concern, control, curiosity and confidence, which helps adolescents fulfill their duties related to work dedicated to career development and discovery, thus creating career adaptability processes, as well as how individuals will formulate their career goals and educational and vocational choices (Guan et al., 2016).

Adolescents' second important predictor of career adaptability is perceived social support from teachers. It has been found that adolescents' awareness of self, career adaptability and vocational skills are related to career adaptability due to instrumental and educational interventions provided by their teachers (Han \& Rojewski, 2009). According to the findings, adolescents' social support perceived by their friends was the lowest predictor of career adaptability. Cheung and Jin (2016) explain that adolescents have a high likelihood of getting help from teachers and parents who are more experienced than their peers in career-related processes because they and their peers have relatively less experience with the business world. Therefore, it can be said that in the process of adolescence, the roles of family, teacher, and friends are different in the process of career development of the adolescents based on the findings of this research that investigated the relationship between adolescents' perceived social support and career adaptability. As a result, career adaptability and social support variables as a predictor of subjective well-being of high school students account for $49 \%$ of the variance. Career adaptability was found as the most important predictor of subjective well-being. Savickas' career construction theory (2002), which consistently incorporates career adaptability with how personal goals are linked to subjective well-being (Hartung \& Taber, 2008), aims to understand how an individual can facilitate his or her overall life satisfaction and happiness. Research in this context supports the relationship between adolescents' career adaptability and subjective well-being in accordance with research findings (Hirschi, 2009; Creed, Prideaux \& Patton, 2005; Konstam et al., 2015).

Another predictor of subjective well-being is social support, which is perceived from the family and the teacher. Adolescence, which is the transition from childhood to adulthood, is characterized as a unique period in which 
multiple physical and psychological changes occur and individuals' social demands increase (Vondra \& Garbarino, 1988). In this period, social support of individuals often referred to as the existence or quality of social relations or, in particular, family, friendship, or academic/work life relations, affect the subjective well-being of the adolescents considerably (Huure, 2000). According to du Bois-Reymond and Ravesloot (1994), family and friends are important social support resources for individuals. In addition to this, siblings, relatives and teachers are also important resources of social support that individuals have in adolescence (Furman \& Buhrmester, 1985). In line with these findings, perceived social support from parents have played an important role in the subjective well-being of adolescents and perceived social support from friends also play an important role in their subjective well-being (Wang, Kouvonen, Satka, \& Julkunen, 2018; Huure, 2000; Shaber et al., 1997; Robinson, 1995).

\section{Conclusion, Limitation, and Recommendations}

Subjective well-being, career adaptability and perceived social support are found to be significant at different levels. The perceived social support from family, teachers and friends are variables that predict the career adaptability of high school students. The most important predictor is the social support perceived from the family as expected. Based on these findings, social support has an important effect on career adaptability, which is the ability to cope with the difficulties encountered in the career process and experiences. Efforts to improve the career adaptability of students, family and support of teachers, as well as friends, are needed.

In this study, career adaptability was found to be a significant predictor of subjective well-being. Based on this result, efforts to develop students' career adaptability may also enhance their subjective well-being. This situation emphasizes the importance of studies for career adaptability in schools. In this context, the study group is limited to high school students. Since career adaptability is a variable that is also examined in employees, a broader perspective regarding both social support and subjective well-being can be obtained if studies include different business sectors.

\section{References}

Buyukgoze-Kavas, A. (2014). Validation of the Career Adapt-Abilities Scale-Turkish form and its relation to hope and optimism. Australian Journal of Career Development, 23(3), 125-132. https://doi.org/10.1177/1038416214531931

Canbay, H. (2010). Lise öğrencilerinin öznel iyi oluş düzeyleri ile sosyal beceri düzeyleri arasındaki ilişkinin incelenmesi (Yayımlanmamış doktora tezi). DEÜ Eğitim Bilimleri Enstitüsü.

Celen-Demirtas, S., Konstam, V., \& Tomek, S. (2015). Leisure activities in unemployed emerging adults: Links to career adaptability and subjective well - being. The Career Development Quarterly, 63(3), 209-222. https://doi.org/10.1002/cdq.12014

Cheung, R., \& Jin, Q. (2016). Impact of a career exploration course on career decision making, adaptability, and relational support in Hong Kong. Journal of Career Assessment, 24(3), 481-496. https://doi.org/10.1177/1069072715599390

Cohen, S., \& Hoberman, H. M. (1983). Positive events and social supports as buffers of life change stress. Journal of Applied Social Psychology, 13(2), 99-125. https://doi.org/10.1111/j.1559-1816.1983.tb02325.x

Creed, P. A., \& Hughes, T. (2013). Career development strategies as moderators between career compromise and career outcomes in emerging adults. Journal of Career Development, 40, 146-163. https://doi.org/10.1177/0894845312437207

Creed, P. A., Fallon, T., \& Hood, M. (2009). The relationship between career adaptability, person and situation variables, and career concerns in young adults. Journal of Vocational Behavior, 74(2), 219-229. https://doi.org/10.1016/j.jvb.2008.12.004

Creed, P., Prideaux, L. A., \& Patton, W. (2005). Antecedents and consequences of career decisional states in adolescence: A longitudinal study. Journal of Vocational Behavior, 67, 397-412. https://doi.org/10.1016/j.jvb.2004.08.008

Deiner, E. (2001). Subjective well-being: The science of happiness and a proposal for a national Index. American Psychologist, 55(1), 34-43. https://doi.org/10.1037/0003-066X.55.1.34

Diener, E. (1996). Traits can be powerful, but are not enough: Lessons from subjective well-being. Journal of research in personality, 30(3), 389-399. https://doi.org/10.1006/jrpe.1996.0027

Diener, E. D., Emmons, R. A., Larsen, R. J., \& Griffin, S. (1985). The satisfaction with life scale. Journal of personality assessment, 49(1), 71-75. https://doi.org/10.1207/s15327752jpa4901_13 
Dost, M. T. (2007). Üniversite öğrencilerinin yaşam doyumunun bazı değişkenlere göre incelenmesi. Pamukkale Üniversitesi Ĕgitim Fakültesi Dergisi, 22(22), 132-143.

du Bois-Reymond, M., \& Ravesloot, J. (1994). The Roles of Parents and Peers in the Sexual and Relational Socialization of Adolescents. In K. Hurrelmann, \& S. F. Hamilton (Eds.), Social Problems and Social Contexts in Adolescence: Perspectives Across Boundaries. New York: Aldine de Gruyter, 1996:175-97.

Eryılmaz, A. (2010). Ergenlerde öznel iyi oluşu artırma stratejilerini kullanma ile akademik motivasyon arasındaki ilişki. Klinik Psikiyatri, 13, 77-84.

Eryılmaz, A. (2011). Ergen Öznel İyi Oluşunun, Öznel İyl Oluşu Arttırma Stratejilerini Kullanma ile Yaşam Amaçlarını Belirleme Açısından İncelenmesi. Dusunen Adam: Journal of Psychiatry \& Neurological Sciences, 24(1), 44-51. https://doi.org/10.5350/DAJPN2011240106

Eryılmaz, A., \& Hasan, A. T. A. K. (2011). Ergen Öznel İyi Oluşunun, Öz Saygı Ve İyimserlik Eğilimi İle İlişkisinin İncelenmesi. Elektronik Sosyal Bilimler Dergisi, 37(37), 170-181.

Furman, W., \& Buhrmester, D. (1992). Age and sex differences in perceptions of networks of personal relationships. Child Development, 63(1), 103-115. https://doi.org/10.1111/j.1467-8624.1992.tb03599.x

Gençöz, T. (2000). Positive and Negative Affect Schedule: A study of validity and reliability. Türk Psikoloji Dergisi, 15(46), 19-28.

Ginevra, M. C., Magnano, P., Lodi, E., Annovazzi, C., Camussi, E., Patrizi, P., \& Nota, L. (2018). The role of career adaptability and courage on life satisfaction in adolescence. Journal of adolescence, 62, 1-8. https://doi.org/10.1016/j.adolescence.2017.11.002

Ginevra, M. C., Pallini, S., Vecchio, G. M., Nota, L., \& Soresi, S. (2016). Future orientation and attitudes mediate career adaptability and decidedness. Journal of Vocational Behavior, 95, 102-110. https://doi.org/10.1016/j.jvb.2016.08.003

Grandey, A. A., Tam, A. P., \& Brauburger, A. L. (2002). Affective states and traits in the workplace: Diary and survey data from young workers. Motivation and Emotion, 26(1), 31-55. https://doi.org/10.1023/A:1015142124306

Guan, P., Capezio, A., Restubog, S. L. D., Read, S., Lajom, J. A. L., \& Li, M. (2016). The role of traditionality in the relationships among parental support, career decision-making self-efficacy and career adaptability. Journal of Vocational Behavior, 94, 114-123. https://doi.org/10.1016/j.jvb.2016.02.018

Han, H., \& Rojewski, J. W. (2015). Gender-specific models of work-bound Korean adolescents' social supports and career adaptability on subsequent job satisfaction. Journal of Career Development, 42(2), 149-164. https://doi.org/10.1177/0894845314545786

Hartung, P. J., \& Taber, B. J. (2008). Career construction and subjective well-being. Journal of Career Assessment, 16, 75-85. https://doi.org/10.1177/1069072707305772

Headey, B., \& Wearing, A. (1989). Personality, life events, and subjective well-being: Toward a dynamic equilibrium model. Journal of Personality and Social psychology, 57(4), 731-739. https://doi.org/10.1037/0022-3514.57.4.731

Hirschi, A. (2009). Career adaptability development in adolescence: Multiple predictors and effect on sense of power and life satisfaction. Journal of Vocational Behavior, 74(2), 145-155. https://doi.org/10.1016/j.jvb.2009.01.002

Huurre, T. (2000). Psychosocial Development and Social Support among Adolescents with Visual İmpairment (Academic Dissertation, University of Tampere, Finland).

Işık, E. (2014). Çocuk kariyer gelişimi ile yaşam doyumu ve durumluk kaygı arasındaki ilişkilerin incelenmesi. Ilkögretim Online, 13(2), 682-693.

Köker, S. (1991). Normal ve sorunlu ergenlerin yaşam doyumu düzeyinin karşılaşstırlmassı. Yayımlanmamış Yüksek Lisans Tezi, Ankara Üniversitesi, Sosyal Bilimler Enstitüsü, Ankara

Konstam, V., Celen-Demirtas, S., Tomek, S., \& Sweeney, K. (2015). Career adaptability and subjective well-being in unemployed emerging adults: A promising and cautionary tale. Journal of Career Development, 42(6), 463-477. https://doi.org/10.1177/0894845315575151

Kracke, B. (2002). The role of personality, parents and peers in adolescents career exploration. Journal of Adolescence, 25(1), 19-30. https://doi.org/10.1006/jado.2001.0446 
Myers, D. G. (2000). The funds, friends, and faith of happy people. American Psychologist, 55(1), 56. https://doi.org/10.1037/0003-066X.55.1.56

Myers, D. G., \& Diener, E. (1995). Who is happy? Psychological Science, 6(1), 10-19. https://doi.org/10.1111/j.1467-9280.1995.tb00298.x

Negru-Subtirica, O., \& Pop, E. I. (2016). Longitudinal links between career adaptability and academic achievement in adolescence. Journal of Vocational Behavior, 93, 163-170. https://doi.org/10.1016/j.jvb.2016.02.006

Oral, A. G. L., \& Sevinç, K. Ö. S. E. (2011). Hekimlerin Duygusal Emek Kullanımı İle İş Doyumu Ve Tükenmişlik Düzeyleri Arasındaki İlişkiler Üzerinde Bir Araştırma. Süleyman Demirel Üniversitesi İktisadi Ve İdari Bilimler Fakültesi Dergisi, 16(2), 463-492.

Özdamar, K. (2016). Eğitim, sağlık ve davranış bilimlerinde ölçek ve test gelişitrme yapısal eşitlik modellemesi. Eskişehir: Nisan.

Restubog, S. L. D., Bordia, P., \& Bordia, S. (2011). Investigating the role of psychological contract breach on career success: Convergent evidence from two longitudinal studies. Journal of vocational behavior, 79(2), 428-437. https://doi.org/10.1016/j.jvb.2011.01.006

Robinson, N. S. (1995). Evaluating the Nature of Perceived Support and its Relation to Perceived Self-Worth in Adolescents. Journal of Research on Adolescence (Lawrence Erlbaum), 5(2), 253-280. doi:10.1111/1532-7795.ep11301600

Rogers, M. E., Creed, P. A., \& Glendon, A. I. (2008). The role of personality in adolescent career planning and exploration: A social cognitive perspective. Journal of Vocational Behavior, 73(1), 132-142. https://doi.org/10.1016/j.jvb.2008.02.002

Şahin, G. N. (2011). Üniversite öğrencilerinin kendini açma, öznel iyi oluş ve algıladıkları sosyal destek düzeylerinin karşılaştırılması. Yayınlanmamış yüksek lisans tezi, Dokuz Eylül Üniversitesi Eğitim Bilimleri Enstitüsü, İzmir.

Savickas, M. L. (1997). Career adaptability: An integrative construct for life-span, life-space theory. The Career Development Quarterly, 45(3), 247-259. https://doi.org/10.1002/j.2161-0045.1997.tb00469.x

Savickas, M. L. (2002). Career construction: A developmental theory of vocational development. In D. Brown (Ed.), Career choice and development (4th ed., pp. 149-205). San Francisco, CA: Jossey-Bass.

Savickas, M. L., \& Porfeli, E. J. (2012). Career Adapt-Abilities Scale: Construction, reliability, and measurement equivalence across 13 countries. Journal of Vocational Behavior, 80(3), 661-673. https://doi.org/10.1016/j.jvb.2012.01.011

Saygın, Y., \& Arslan, C. (2009). Üniversite öğrencilerinin sosyal destek, benlik saygısı ve öznel iyi oluş düzeylerinin incelenmesi. Selçuk Üniversitesi Ahmet Keleşoğlu Eğitim Fakültesi Dergisi, 28, 207-222.

Sheeber, L., Hops, H., Alpert, A., Davis, B., \& Andrews, J. (1997). Family support and conflict: Prospective relations to adolescent depression. Journal of Abnormal Child Psychology, 25(4), 333-344. https://doi.org/10.1023/A:1025768504415

Shin, D. C., \& Johnson, D. M. (1978). Avowed happiness as an overall assessment of the quality of life. Social Indicators Research, 5(1-4), 475-492. https://doi.org/10.1007/BF00352944

Turner, S., \& Lapan, R. T. (2002). Career self-efficacy and perceptions of parent support in adolescent career $\begin{array}{llll}\text { development. The Career Development } & \text { Quarterly, }\end{array}$ https://doi.org/10.1002/j.2161-0045.2002.tb00591.x

Viswesvaran, C., Sanchez, J. I., \& Fisher, J. (1999). The role of social support in the process of work stress: A meta-analysis. Journal of Vocational Behavior, 54(2), 314-334. https://doi.org/10.1006/jvbe.1998.1661

Vondra, J., \& Garbarino, J. (1988). Social influences on adolescent behavior problems. In Salzinger, S., Antrobus, J., and Hammer, M. (eds.), Social Networks of Children, Adolescents, and College Students (pp. 195-224). Lawrence Erlbaum Associates, Hillsdale.

Wang, Z., \& Fu, Y. (2015). Social support, social comparison, and career adaptability: A moderated mediation model. Social Behavior And Personality: An International Journal, 43(4), 649-659. https://doi.org/10.2224/sbp.2015.43.4.649

Wang, Z., Kouvonen, A., Satka, M., \& Julkunen, I. (2018). Parental Social Support and Adolescent Well-Being: 
A Cross-Sectional Study in China. Child Indicators Research, 1-19. https://doi.org/10.1007/s12187-018-9547-2

Watson, D., Clark, L. A., \& Tellegen, A. (1988). Development and validation of brief measures of positive and negative affect: The PANAS scales. Journal of Personality and Social Psychology, 54(6), 1063-1070. https://doi.org/10.1037/0022-3514.54.6.1063

Wiesenberg, F., \& Aghakhani, A. (2007). An exploration of graduate students' career transition experiences. Canadian Journal of Counselling, 41(2), 107-123.

Yetim, Ü. (1993). Life satisfaction: A study based on the organization of personal projects. Social Indicators Research, 29(3), 277-289. https://doi.org/10.1007/BF01079516

Yıldırım, İ. (1997). Algılanan sosyal destek ölçeğinin geliştirilmesi, güvenirliği ve geçerliği. Hacettepe Üniversitesi Ĕ̈itim Fakültesi Dergisi, 13(13), 81-87.

Yıldırım, İ. (1998). Akademik başarı düzeyleri farklı olan lise öğrencilerinin bazı değişkenlere göre sosyal destek düzeyleri. Türk Psikolojik Danışma ve Rehberlik Dergisi, 2(10), 33-45.

Yıldırım, İ., \& Ergene, T. (2003). Lise son sınıf öğrencilerinin akademik başarılarının yordayıcısı olarak sınav kaygısı, boyun eğici davranışlar ve sosyal destek. Hacettepe Üniversitesi Eğitim Fakültesi Dergisi, 25(25), 224-234.

\section{Copyrights}

Copyright for this article is retained by the author(s), with first publication rights granted to the journal.

This is an open-access article distributed under the terms and conditions of the Creative Commons Attribution license (http://creativecommons.org/licenses/by/4.0/). 